\begin{tabular}{|c|c|c|c|c|c|c|}
\hline \multirow{4}{*}{ Impact Factor: } & ISRA (India) & $=3.117$ & SIS (USA) & $=0.912$ & ICV (Poland) & $=6.630$ \\
\hline & ISI (Dubai, UAE & $=0.829$ & РИНЦ (Russia) & $=0.156$ & PIF (India) & $=1.940$ \\
\hline & GIF (Australia) & $=0.564$ & ESJI (KZ) & $=8.716$ & IBI (India) & $=4.260$ \\
\hline & JIF & $=1.500$ & SJIF (Morocco) & $=5.667$ & OAJI (USA) & $=0.350$ \\
\hline
\end{tabular}

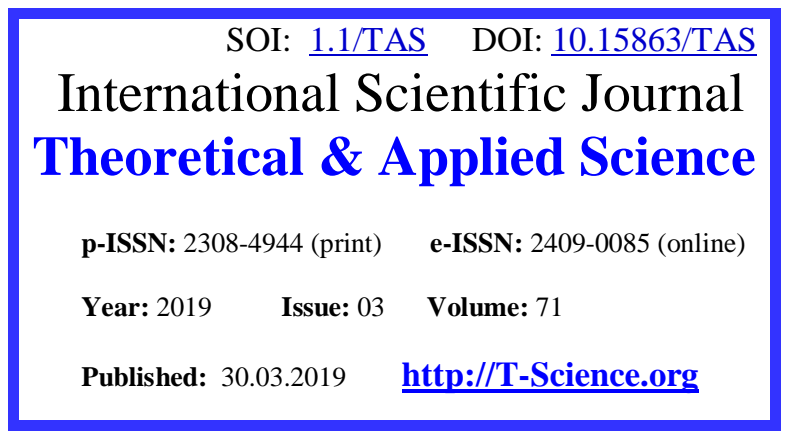

UDK 378.046.4
QR - Issue

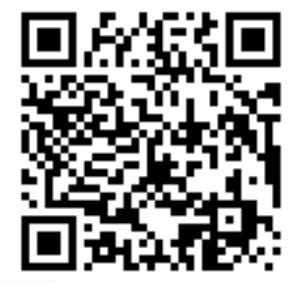

Farkhod Musajonovich Nishonov

Teacher of Mathematics, Academic Lyceum of the Fergana Polytechnic Institute, Republic of Uzbekistan

Nilufar Tolibovna Ehsonova

Teacher of Mathematics, State Secondary School No. 33, Besharik, Republic of Uzbekistan

Islombek Shukhratjon ugli Tolibov 3rd year student, Fergana Polytechnic Institute, Republic of Uzbekistan ferghana@inbox.ru

\title{
PROFESSIONAL GROWTH OF THE TEACHER OF MATHEMATICS OF THE ACADEMIC LYCEUM IN THE CONDITIONS OF TECHNOLOGIES OF THE DIGITAL EDUCATIONAL SPACE
}

Abstract: The paper studies some topical issues of postgraduate education of a mathematics teacher. The authors in the article argue that one of the most important problems is the advanced training of a mathematics teacher and his professional career. The authors proposed the direction of teacher self-improvement and the formation of the vector of his professional development. The most significant of them are the actualization of the new approach to the formation and development of the subject informational and educational environment; use of the Moodle distance learning system; development of the ability to innovate professional activities; the formation of a digital portfolio of a mathematics teacher, the formation and development of information and communication competence of a mathematics teacher.

Key words: Distance education, information and communication educational technologies, career growth, education, professional development, professional competence, professional growth, a teacher of mathematics of the academic lyceum, digital technologies.

Language: English

Citation: Nishonov, F. M., Ehsonova, N. T., \& Tolibov, I. S. (2019). Professional growth of the teacher of mathematics of the academic lyceum in the conditions of technologies of the digital educational space. ISJ Theoretical \& Applied Science, 03 (71), 534-537.

Soi: http://s-o-i.org/1.1/TAS-03-71-52 Doi: crossef https://dx.doi.org/10.15863/TAS.2019.03.71.52

\section{Introduction}

The large-scale reforms carried out over the years of independence laid a solid foundation of national statehood and sovereignty, and formed a new system for the provision of educational services for the population. The refusal of the administrativecommand management of the national education system, the phased implementation of new educational programs contributed to the integration of the domestic educational system to take a step towards integration into the global educational network.

At the same time, a comprehensive analysis of the country's passed stage of development, the changing conjuncture of the world economy in the context of globalization, and increasing competition require the development and implementation of radically new ideas and principles for the further sustainable and advanced development of the national education system. 


\begin{tabular}{|c|c|c|c|c|c|c|}
\hline \multirow{4}{*}{ Impact Factor: } & ISRA (India) & $=3.117$ & SIS (USA) & $=0.912$ & ICV (Poland) & $=6.630$ \\
\hline & ISI (Dubai, UAE & $=0.829$ & РИНЦ (Russia & $=0.156$ & PIF (India) & $=1.940$ \\
\hline & GIF (Australia) & $=0.564$ & ESJI (KZ) & $=8.716$ & IBI (India) & $=4.260$ \\
\hline & JIF & $=1.500$ & SJIF (Morocco & $=5.667$ & OAJI (USA) & $=0.350$ \\
\hline
\end{tabular}

The concept of education reform, developed in Uzbekistan, provided for the most important goals: reorientation of the education system to a market economy and an open society; the creation of equal educational opportunities, as a condition for raising the standard of living of the population; improvement of the education financing system in order to ensure stable and high-quality educational services and increase the efficiency of resource use; improving the management of the education sector. With the gradual implementation of the laws of the Republic of Uzbekistan "On Education"[1] and "On the National Program for Personnel Training"[2], new prospects for real changes in the system of continuing education have been opened, and favorable conditions have been created for the development and introduction of state educational standards.

In order to fundamentally improve the effectiveness of the reforms, create conditions for ensuring the comprehensive and accelerated development of the state and society, implement the priority directions for modernizing the country and liberalizing all spheres of life, it was approved based on a comprehensive study of current issues and concerns of the population, analysis of current legislation, law enforcement practices and international best practices, as well as broad public discussion. The action Strategy for the five priorities Areas of the Republic of Uzbekistan in 2017 - 2021 years [3].

The implementation of this Strategy is inextricably linked with the deepening and liberalization of the national education system. In particular, the development of new directions of higher education, modern educational standards based on best practices of developed countries of the world.

\section{Materials and Methods}

The system analysis of educational standards in the USA, Germany and South Korea made it possible to identify the vectors for the renewal of education in the context of systemic changes in society. In our opinion, these include:

- Gradual formation of a multi-variant educational space, allowing each teacher to design and implement individual educational cards in accordance with professional needs;

- The formation of the teacher's readiness for the effective use of the educational space in the conditions of the formation of the digital economy.

The modern profession of a mathematics teacher in an academic lyceum requires constant selfimprovement, continuous mastery of new types of competencies, both in the subject area and in the field of vocational training methods and technology [4].

As the long-term experience of teaching mathematics in Academic Lyceums of the Fergana Polytechnic Institute and the Fergana State University shows, in the process of professional and career growth, mathematics teachers in the academic lyceum develop various types of competencies; it is advisable to highlight the following: activity competencies such as communication, reflexive and design competencies.

\section{Applied significance of research}

The analysis of educational practice allowed us to identify and formulate the following relevant activities to improve the appropriate level of competence.

1. Development of the ability to innovate professional activities. Each mathematics teacher of an academic lyceum must have a level of methodological culture and a prepared readiness for continuous education throughout the whole pedagogical activity. The purpose of the professional growth of a mathematics teacher in an academic lyceum is his active involvement in the system of advanced training and the development of the professional competence of mathematics teachers in accordance with modern requirements for teaching mathematics in academic lyceums in the context of deep modernization of education.

In general, this is implemented by the Resolution of the Cabinet of Ministers of the Republic of Uzbekistan No. 278 dated September 26, 2012, "On measures to further improve the system of retraining and advanced training of teachers of higher educational institutions" in the Regional Center for Retraining and Advanced Training of Pedagogical Personnel at the Fergana State University [5]. The center for the organization of advanced training in the block of mathematical and natural sciences has powerful teaching tools, has new lecture halls with modern multimedia equipment, high-speed Internet access to the global network, and computer classes equipped with interactive boards, electronic libraries and other scientific and technological achievements.

In the system of raising the level of professional competence of a mathematics teacher of academic lyceums, the Regional Center uses modern forms and methods of organizing the educational process in accordance with the basic requirements for the content of additional professional educational programs:

- new interactive pedagogical, information and communication technologies;

- educational and methodical complexes;

- distance learning technologies;

- methodologies for the development and maintenance of e-learning courses;

- Internet technologies;

- modern information networks and others.

2. Accompanying the preparation of a mathematics teacher of an academic lyceum after completing the relevant course at the Regional Center for Retraining and Advanced Training of Teachers by Creative Personality Tasks in the Direction of a 


\begin{tabular}{|c|c|c|c|c|c|c|}
\hline \multirow{4}{*}{ Impact Factor: } & ISRA (India) & $=3.117$ & SIS (USA) & $=0.912$ & ICV (Poland) & $=6.630$ \\
\hline & ISI (Dubai, UAE & $=0.829$ & РИНЦ (Russia & $=0.156$ & PIF (India) & $=1.940$ \\
\hline & GIF (Australia) & $=0.564$ & ESJI (KZ) & $=8.716$ & IBI (India) & $=4.260$ \\
\hline & JIF & $=1.500$ & SJIF (Morocco & $=5.667$ & OAJI (USA) & $=0.350$ \\
\hline
\end{tabular}

Research Topic or Thesis for a Doctor of Philosophy in Mathematics.

The following tasks may be proposed as tasks for independent work:

- development of visual aids for use in the process of teaching students to implement each of the stages of the process of mathematical modeling in solving problems using the method of equations and inequalities [6];

- development of methods for introducing the concept of "antiderivative" and the main properties of antiderivative;

- methodological development on the introduction of the concept of trigonometric functions of a numeric argument [7].

3. One of the rapidly developing and progressive forms of modern education is the Internet courses, which are actively developed and promoted in world education. Thus, in the conditions of active use of digital learning technologies, the Moodle distance learning system is being successfully tested at the Regional Center. This method is focused primarily on the organization of interaction between the teacher and students, both in the form of traditional distance learning courses, and to support full-time study. Moodle is a course management system (e-learning), also known as a learning management system or a virtual learning environment. It is an abbreviation of English. Modular Object-Oriented Dynamic Learning Environment [8]. It is a free web application that provides the ability to create online learning resources.

4. Formation and further development of information and communication competence of the mathematics teacher of the academic lyceum as one of the urgent problems of our time. The development of communication links between the Regional Center for retraining and advanced training of teachers and educational institutions, in our opinion, should include the following:

- implementation of academic mobility;

- professional short-term internships;

- exchange of professional experience between colleagues;

- organization of republican and international conferences;

- development of joint projects, etc.

5. Informatization processes, the widespread use of information and communication technologies (ICT) are a condition for the implementation of the State Program for the Development of Education and Science in Uzbekistan. Sh.M. Mirziyoyev's presidential initiatives and the strategy of building the information society in Uzbekistan form a request not only for updating the educational environment of educational institutions, but also for the efficient use of its resources [9]. And this, in turn, is impossible without continuous professional development of teachers. In this case, the information educational environment is a sphere and means of developing their professional competence. At the same time, a continuous change in its potential requires the advanced development of ICT competence of teachers.

The main purpose of the preparation of mathematics teachers is to promote the formation of the readiness and ability of the teacher to use ICT in their professional activities. ICT components (technical, program, methodical and informational) allow defining the system of tasks when planning the process of training teachers.

1) Improving and developing skills in the use of PCs, peripherals, local and global networks.

2) Acquaintance with programs of general and educational purposes, modeling environments, as well as with the possibilities of their use in the educational process.

3) Mastering the methods of teaching mathematics using ICT.

4) Development of skills and skills in working with electronic information (search, analysis, systematization, conversion, etc.) [10].

Based on the above, a mathematics teacher at an academic lyceum will be able to independently form his own digital portfolio, which will contribute to:

- the formation of integrated ideas about the current state of mathematical education;

- introducing into the circle of professional activity of a specialist problems related to current issues of teaching mathematics and developing skills for obtaining, analyzing and generalizing mathematical information;

- development of a mathematics teacher's ability to conduct methodological and expert work in the field of mathematics.

The digital portfolio, as a basic element of the formation of professional competencies, will allow the mathematics teacher of the academic lyceum:

- to fix the main directions of development of mathematics education and the particularities of teaching mathematics in various age groups of students;

- implement creative projects;

- to use modern learning technologies taking into account the individual characteristics and abilities of students in the study of the school course of mathematics.

Studies have shown that the following can be highlighted as the main elements of a digital portfolio:

- block of subject knowledge and mathematical foundations of the discipline,

- including theoretical knowledge of mathematics and methods of teaching mathematics, a glossary on the subject;

- regulatory block containing concepts, regulatory and legal materials that allow the future teacher to form an understanding of the main 


\begin{tabular}{|c|c|c|c|c|c|c|}
\hline \multirow{4}{*}{ Impact Factor: } & ISRA (India) & $=3.117$ & SIS (USA) & $=0.912$ & ICV (Poland) & $=6.630$ \\
\hline & ISI (Dubai, UAE & $=0.829$ & РИНЦ (Russia) & $=0.156$ & PIF (India) & $=1.940$ \\
\hline & GIF (Australia) & $=0.564$ & ESJI (KZ) & $=8.716$ & IBI (India) & $=4.260$ \\
\hline & JIF & $=1.500$ & SJIF (Morocco & $=5.667$ & OAJI (USA) & $=0.350$ \\
\hline
\end{tabular}

directions of modern modernization of mathematical education, the introduction of new educational technologies;

- block of methodical developments of a mathematics teacher, formed in the process of studying the discipline, and allowing to give students the necessary amount of methodological knowledge;

- a block of realized research projects that will help the teacher to develop the research competencies necessary for the productive pedagogical activity of the mathematics teacher of the academic lyceum;

- a block of informational and objective resources on mathematical disciplines, formed from resource bases, websites and portals of teacherspractitioners, psychological and pedagogical tests resources, allowing to diagnose and analyze experimental work;

- Interactive block, which includes subscription materials, incoming emails, invitations, discussions in social networks (Moodle, LinkedIn, Scholar.google.com, etc.).

\section{Conclusion}

In conclusion, it should be noted that the abovementioned directions of professional growth of a mathematics teacher at an academic lyceum can contribute to the professional integration of future and working teachers, and in general, the formation of personnel policies in the preparation of teachersmathematicians in the Fergana Valley in terms of mastering digital educational technologies.

\section{References:}

1. (n.d). Vedomosti Oliy Mazhlisa Respubliki Uzbekistan, 1997 g., № 9, st. 225; 2013 g., № 41, st. 543; Natsional'naya baza dannykh zakonodatel'stva, $\quad 05.01 .2018 \quad$ g., № 03/18/456/0512, $19.04 .2018 \quad$ g., № $03 / 18 / 476 / 1087$

2. (2018). Natsional'naya baza dannykh zakonodatel'stva, $\quad 05.01 .2018 \quad$ g., № 03/18/456/0512

3. (2017). O strategii deystviy po dal'neyshemu razvitiyu Respubliki Uzbekistan. Ukaz Prezidenta Respubliki Uzbekistan № UP-4947 ot 7 fevralya 2017 g., Sobraniye zakonodatel'stva Respubliki Uzbekistan, № 6, st. 70.

4. Shkerina, L. V., \& Panasenko, A. N. (2012). Modelirovaniye matematicheskoy kompetentsii bakalavra-budushchego uchitelya matematiki. Innovatsii v nepreryvnom obrazovanii, (4), 5963.

https://cyberleninka.ru/article/n/modelirovaniematematicheskoy-kompetentsii-bakalavrabuduschego-uchitelya-matematiki-1

5. (2012). O merakh po dal'neyshemu sovershenstvovaniyu sistemy perepodgotovki i povysheniya kvalifikatsii pedagogicheskikh kadrov vysshikh obrazovatel'nykh uchrezhdeniy. Postanovleniye Kabineta Ministrov Respubliki Uzbekistan № 278 ot 26 sentyabrya 2012 g., Sobraniye zakonodatel'stva Respubliki Uzbekistan, № 39, st. 453.
6. Nishonov, F. M, \& Kurpayanidi, K. I (2018). Some questions of design of tasks in mathematics. ISJ Theoretical \& Applied Science, № 09 (65), 41-44. Soi: http://s-o-i.org/1.1/TAS09-65-7 Doi: https://dx.doi.org/10.15863/TAS.2018.09.65.7

7. Kurpayanidi, K. I., \& Nishonov, F. M. (2018). Konstruirovaniye sistem zadach po matematike. Mezhdunarodnyy zhurnal gumanitarnykh $i$ yestestvennykh nauk, (10-1).

8. Sorokin, V. V., Natrova, A. S., \& Yerofeyev, A. Y. (2015). Modul'naya ob"yektnooriyentirovannaya dinamicheskaya obuchayushchaya sreda (modular objectoriented dynamic learning environment) $\mathrm{v}$ patologicheskoy anatomii. Aktual'nyye problemy eksperimental'noy i klinicheskoy meditsiny, 416417.

9. (2018). Poslaniye Prezidenta Respubliki Uzbekistan Shavkata Mirziyoeva Oliy Mazhlisu. Elektronnyy resurs. Retrieved 2019, from http://www.uza.uz/ru/politics/poslanieprezidenta-respubliki-uzbekistan-shavkatamirziyeevas-28-12-2018

10. Frolova, L. G., \& Shul'ts, V. Y. (2014). Organizatsiya matematicheskogo prostranstva $\mathrm{V}$ shkole. Obrazovatel'nyye resursy $i$ tekhnologii, (1 (4)). 